\title{
INDIVIDUAL VARIABILITY IN MORPHOMETRY AND EMERGENCE OF SEEDS OF Combretum leprosum
}

\author{
VARIABILIDADE INDIVIDUAL NA MORFOMETRIA E EMERGÊNCIA DE \\ Combretum leprosum
}

\begin{abstract}
Renan da Cruz PAULINO ${ }^{1}$; Maria de Fatima Barbosa COELHO ${ }^{2}$; Gabrielly Paula de Sousa Azevedo HENRIQUES ${ }^{3}$; Jeferson Luis Dallabona DOMBROSKI ${ }^{4}$

1. Doutorando do Programa de Pós Graduação em Fitotecnia, Universidade Federal Rural do Semi Árido - UFERSA, Mossoró, RN, Brasil. renanesam@ @otmail.com; 2. Professora Titular, Programa de Pós Graduação em Agricultura Tropical, Universidade Federal de Mato Grosso, UFMT, Cuiabá, MT, Brasil. coelhomfstrela@gmail.com; 3. Doutoranda do Programa de Pós Graduação em Fitotecnia, Universidade Federal Rural do Semi Árido - UFERSA, Mossoró, RN, Brasil; Professor Adjunto, Universidade Federal Rural do Semi Árido - UFERSA, Mossoró, RN, Brasil.
\end{abstract}

\begin{abstract}
Combretum leprosum Mart. is a medicinal species of the Brazilian savanna with good potential potential for use in the regeneration of degraded areas, mainly because it is resistant to burning. This study aimed to evaluate the fruit and seed morphometry, emergence and early plant development of C. leprosum. The seeds of $C$. leprosum were extracted from mature fruits from five different mother plants in Mossoró-RN. The fruit and seeds lots varied in length, diameter and mass and mother plant 1 had the lowest seed diameters and mass and also the lower averages for all evaluated characteristics of the seedlings. Seeds of mother plant 2, 3 and 5 had a short period of emergence. There was variation in emergence rates among the individuals. Combretum leprosum individuals has variability in emergence and biometrics of seeds, and these characteristics influence the quality of seedlings.
\end{abstract}

KEYWORDS: Mofumbo. Medicinal plant. Variability. Caatinga.

\section{INTRODUCTION}

The seed origin is an important factor that affects germination, and different plant populations may exhibit genetic variability resulting in different germination behavior (OLIVEIRA et al., 2008; RODRIGUES et al., 2007; WIELEWICKI et al., 2006).

Some studies have been done on the effect of seed origin on the germination behavior of native species. Seeds of Anadenanthera colubrina coming from Tanquinho - BA showed higher germination percentage than those from Cruz das Almas - BA and the authors attribute this behaviors to adaptive differences of this species to the "habitats" where the populations occur, contributing to the ecological and evolutionary success (RODRIGUES et al., 2007). Also, Kopper et al. (2010) observed differences in germination of seeds from different mother plants in Cariniana estrellensis (Raddi) Kuntze. In other study, it was observed differences in behavior of two populations of Cecropia pachystachya Trec. from Inocencia-PI and from the Patanal (LARENTIS; SANTIAGO, 2011).

Variations in the seeds germination behavior from different locations indicates that the areas are subject to variations in temperature, day length, rainfall rates or other environmental effects or that the mother plants genetics can influence the germination behavior (BORGES; RENA, 1993).
Genetic differences between populations may be involved. It was observed that plants of Dimorphandra mollis from Montes Claros, Lontra, Mirabela and Jequitaí had genetic variability (PAULA et al., 2007), and that there was diferrence in the germination percentages presented by the seeds from these four locations (OLIVEIRA et al., 2008).

Some plant species presented variability in seeds characteristics, which ends up affecting the emergence. Kielmeyera coriacea individuals, for example, presented a high degree of uncertainty, low synchronization and spread in relation to emergence averagetime. The correlations between germination and emergence measurements with original data and with residuals were different, showing that the individual's intrinsic variability interferes with the measurement result (SANTANA et al., 2010).

Combretum leprosum Mart. is a Caatinga species which has potential for use in the regeneration of degraded areas, mainly because it is resistant to fire and resprouts after cutting. The leaves and stem bark are used in home medicine as a hemostatic, diaphoretic and tranquilizer. The roots in the form of infusion, decoction or syrup are used for calming, coughs, and the seeds in the form of tea as an anti-hemorrhagic, and against placenta retention (LORENZI; MATOS, 2008). 
The germination of C. leprosum is hypogea, cryptocoledonar with reserve cotyledons (PAULINO et al., 2013). Measurements and descriptions of seed, fruit, emergence and seedling development can be found in Paulino et al. (2013), but how is the variability of these characteristics within individuals of the same species? Descriptive studies of intraspecific variation may support studies of descriptive botany that aim to characterize the species.

In a study with species of the same genus BOGNOUNOU et al. (2010) verified that the germination of Combretum aculeatum, Combretum micranthum and Combretum nigricans were affected differently according to the seed provenance and along the latitudinal gradient. Therefore, this study aimed to morphometric caracterization of fruits, seeds and evaluate the emergence and development of $C$. leprosum. seedlings from different mother plants.

\section{MATERIAL AND METHODS}

The seeds of Combretum leprosum Mart. were obtained from ripe fruit from five mother plants from different localities of Mossoro, RN, Brazil (Table 1). All sites were characterized as being hyperxerophilic savanna with strong human pressure, so antropic degradation was common to all plants habitats. According to Koppen, the climate classification of the region is BSwh (very hot and dry, with rainfall in the summer and early autumn), with an average temperature of $27.2^{\circ} \mathrm{C}$, total annual rainfall of $766 \mathrm{~mm}$ and average relative humidity of $69 \%$ (BORGES et al., 2015).

Table 1. Characteristics and coding of individuals of C. leprosum collected in Mossoró, Rio Grande do Norte, Brazil, 2013.

\begin{tabular}{|c|c|c|c|c|}
\hline $\begin{array}{l}\text { Mother } \\
\text { plant }\end{array}$ & Location & Environment traits & Harvest date & Coordinates \\
\hline 1 & $\begin{array}{l}\text { Federal Rural University of the Semi- } \\
\text { Arid }\end{array}$ & Degraded area & $16 / 09 / 2013$ & $\begin{array}{l}5^{\circ} 12^{\prime} 54^{\prime \prime} \mathrm{S} \\
37^{\circ} 18^{\prime} 23^{\prime \prime} \mathrm{W}\end{array}$ \\
\hline 2 & Community of Barrinha & Urban area & $17 / 09 / 2013$ & $\begin{array}{l}5^{\circ} 14^{\prime} 9^{\prime \prime} \mathrm{S} \\
37^{\circ} 15^{\prime} 36^{\prime \prime} \mathrm{W}\end{array}$ \\
\hline 3 & Community of Raiz & $\begin{array}{l}\text { Nearby country } \\
\text { road }\end{array}$ & $16 / 09 / 2013$ & $\begin{array}{l}5^{\circ} 7^{\prime} 9^{\prime \prime} \mathrm{S} \\
37^{\circ} 20^{\prime} 8^{\prime \prime} \mathrm{W}\end{array}$ \\
\hline 4 & BR 304 & Highway margins & 03/10/2013 & $\begin{array}{l}5^{\circ} 16^{\prime} 20^{\prime \prime} \mathrm{S} \\
37^{\circ} 17^{\prime} 52^{\prime \prime} \mathrm{W}\end{array}$ \\
\hline 5 & BR 304 & Highway margins & 03/10/2013 & $\begin{array}{l}5^{\circ} 16^{\prime} 20^{\prime \prime} \mathrm{S} \\
37^{\circ} 17^{\prime} 55^{\prime \prime} \mathrm{W}\end{array}$ \\
\hline
\end{tabular}

Fruits were collected when they were fully ripened on the plant. Afterward, the mass of 100 fruits and 100 seeds of each individual, coming from the five locations, were weighed in a semianalytical balance (accuracy $0,001 \mathrm{~g}$ ). The length and diameter were measured with the help of a digital caliper with precision of $0.01 \mathrm{~mm}$.

The experiment was conducted in the seedling nursery at the Universidade Federal Rural do Semi-Árido (UFERSA), in the municipality of Mossoró-RN, with geographical coordinates: latitude $5^{\circ} 12^{\prime} 15,5^{\prime \prime}$ South, longitude $37^{\circ} 19 ' 28,8^{\prime \prime}$ West, $20 \mathrm{~m}$ altitude.

The seed water content was determined according to Brasil (2009), using two replicates of 50 seeds from each individual. For the emergence test and the evaluation of the seedlings development, seeds were previously soaked for 24 hours in distilled water (PACHECO et al., 2014). Then the seed were distributed in a coconut fiber substrate, in polystyrene trays of 128 cells with the seed buried flat within a depth of $1 \mathrm{~cm}$. The experiment was irrigated daily and manually.

The experimental design was completely randomized with five treatments (individuals) each treatment with 5 replicates, 40 seeds per experimental unit, totaling 200 seeds per treatment. At the end of the emergence test period, 25 days after sowing, the following characteristics were evaluated: emergence percentage (EP) and mean emergence time (MET):MET (days) $=\frac{\Sigma\left(t_{i} \times n_{i}\right\rangle^{\prime}}{\Sigma n_{i}}$, where $t_{i}$ is the number of days starting from the date of sowing and $n_{i}$ is the number of seeds emerged at each day (LABOURIAU, 1983);

Ten plants from each replicate were measured, totaling 50 seedlings per treatment. They were evaluated: plant height $(\mathrm{PH})$ expressed in $\mathrm{cm}$, measured with a millimeter ruler, from the collar to the apical bud; stem diameter (SD) in mm, using a digital caliper with precision of $0.01 \mathrm{~mm}$; leaves dry mass (LDM), stem dry mass (SDM) and root dry 
mass (RDM), expressed in $\mathrm{mg}$, determined in forced-air oven at $60 \pm 5^{\circ} \mathrm{C}$ to constant mass; total dry mass (TDM), expressed in $\mathrm{mg}$, obtained by adding the dry mass of leaves, stem and root. Mass datas are results of the average of ten seedlings.

The fruit and seeds biometrics results were submitted to statistic descriptive and presented in box plots graphics, where, the ends of the boxes define the 25th and 75th percentiles, with a line at the median and error bars defining the 10th and 90th percentiles.. The others results were presented mean and $95 \%$ confidence interval values.
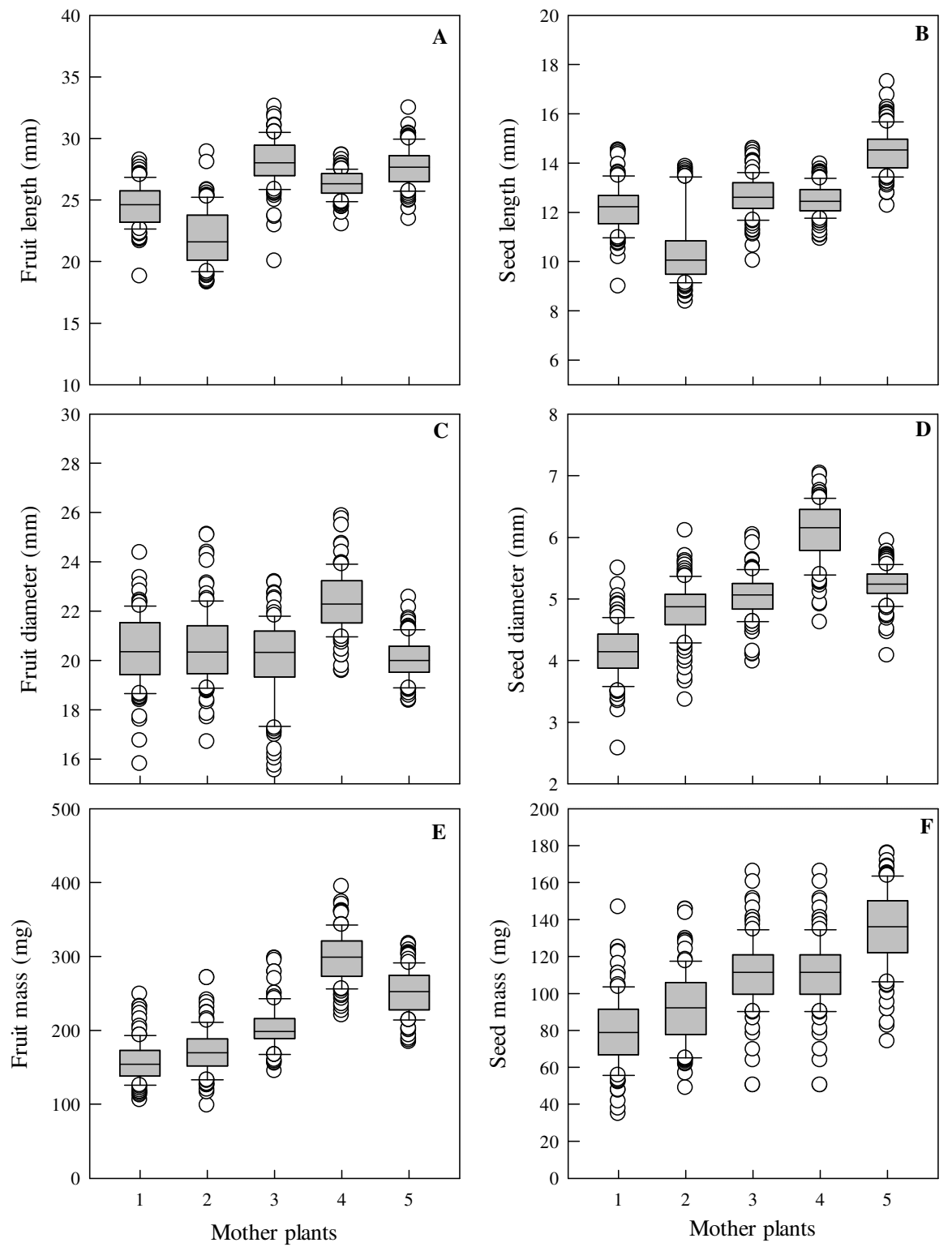

Figure 1. Box plots of fruit length (A), seed length (B), fruit diameter (C), seed diameter (D), fruit mass (E) and seed mass $(\mathrm{F})$ of five $C$. leprosum individuals. $\mathrm{n}=100$

Mother plant 1 had the lowest seed diameters and mass and also the lower averages for all evaluated characteristics of the seedlings (Figure 2). Generally a plant originating from a less

\section{RESULTS AND DISCUSSION}

The fruit and seeds lots varied in length, diameter and mass (Figure 1). It can be observed that the length results did not follow the same pattern as the seeds diameter or the seeds mass, indicating a different from factor among the mother plants. It also can be observed that the seeds diameter is better related to the seeds mass than the seeds length. 

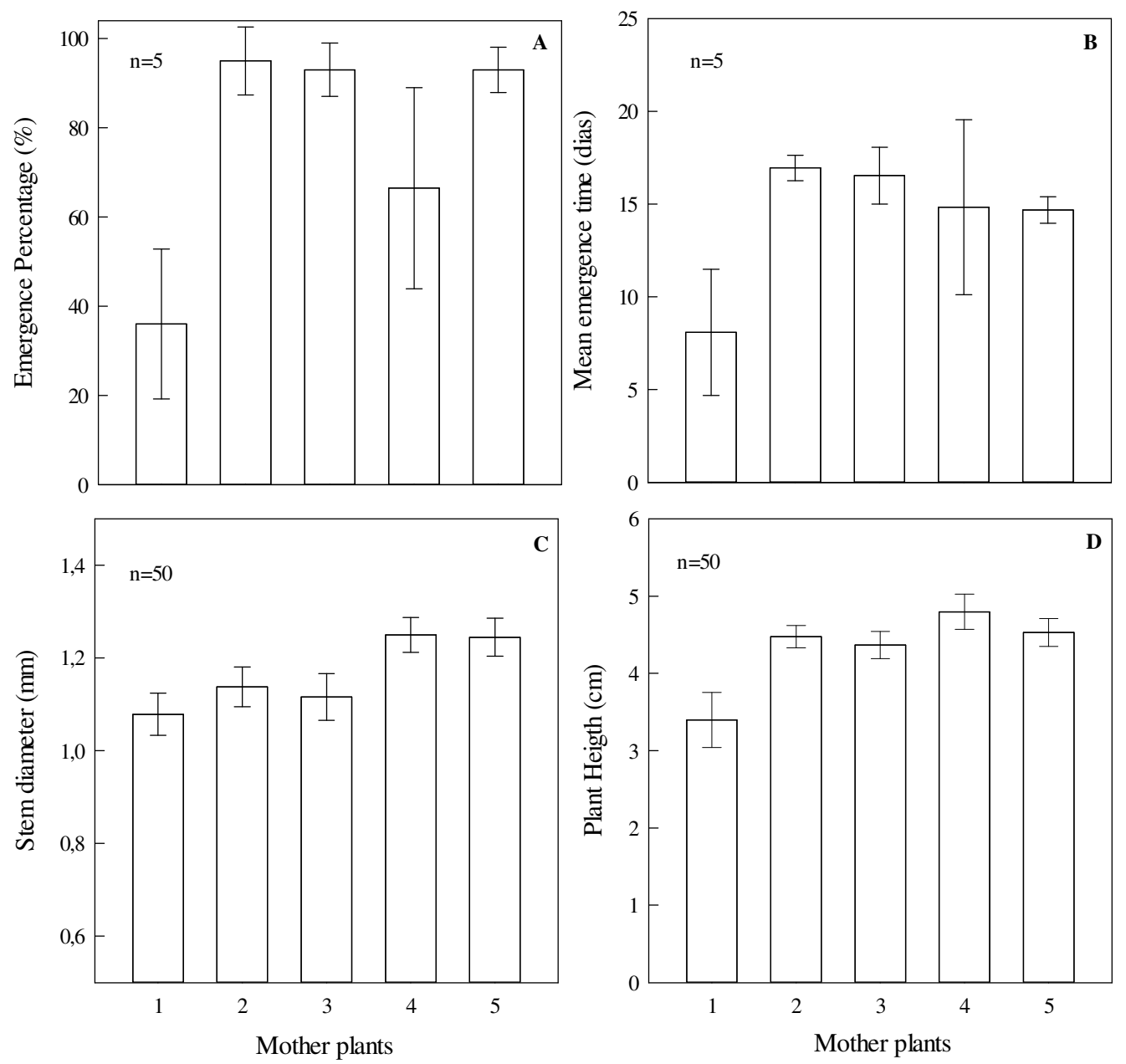

Figure 2. Emergence percentage (A), mean emergence time (B), , stem diameter (C), plant height (D) of five

C. leprosum individuals. (Mean $\pm 95 \%$ C.I.)

The water content was similar between individuals $\quad\left(\mathrm{I}_{1}=12,1 \%, \quad \mathrm{I}_{2}=11,0 \%, \quad \mathrm{I}_{3}=11,3 \%\right.$, $\mathrm{I}_{4}=10,6 \%$ and $\mathrm{I}_{5}=11,0 \%$ ), so it is expected that the seeds moisture was not a relevant factor to the results.

The mother plant 1 and 4 showed EP values below 2, 3 and 5 . however the biometric characteristics of the seedlings, were similar among these individuals. The mother plant 1 showed MET values below than others. This may have occurred as a genetic variation of the species, since it is an allogamus native species (QUIRINO; MACHADO, 2001) and, therefore, the offspring are half-brothers.

The differences in seed emergence observed in this work could be due to genetic differences among the mother plants, in a similar way as found by Oliveira et al. (2008) in Dimorphandra mollis, and supported by Paula et al. (2007) using RAPD molecular markers. The kind of response is variable among species, Copaifera langsdorffii also have presented a high genetic variability (CARVALHO et al., 2010).

The accumulated emergency (Figure 3) clearly indicates the differences between individuals $\mathrm{I}_{2}, \mathrm{I}_{3}$ and $\mathrm{I}_{5}$ had a short period of emergence, from 8 to 13 days after sowing, and from that there was stabilization while $\mathrm{I}_{1}$ and $\mathrm{I}_{4}$ extended that period up to 19 days after sowing.

As for the dry biomass of the vegetative organs and total biomass, there were no significant differences between treatments $\left(\mathrm{I}_{2}, \mathrm{I}_{3}, \mathrm{I}_{4}, \mathrm{I}_{5}\right)$, which are superior to the treatment $I_{1}$ for all dry biomass characteristics (Figure 4). There was a trend of $I_{1}$ to invest more in roots than shoots, his SDM/RDM ratio presented lower results, as the other treatments showed similar behavior in relation to biomass investment. 


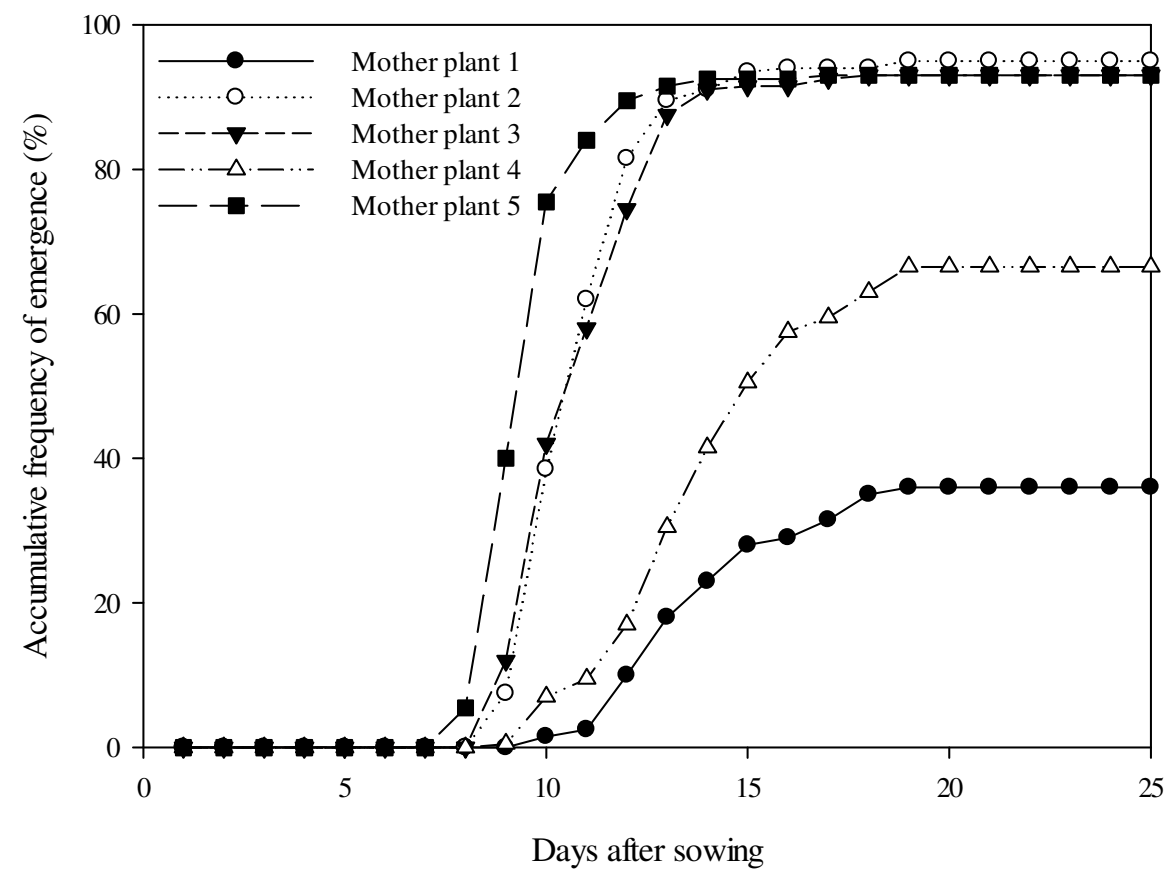

Figure 3. Accumulative frequency of seed emergence of individuals according to the period after sowing.

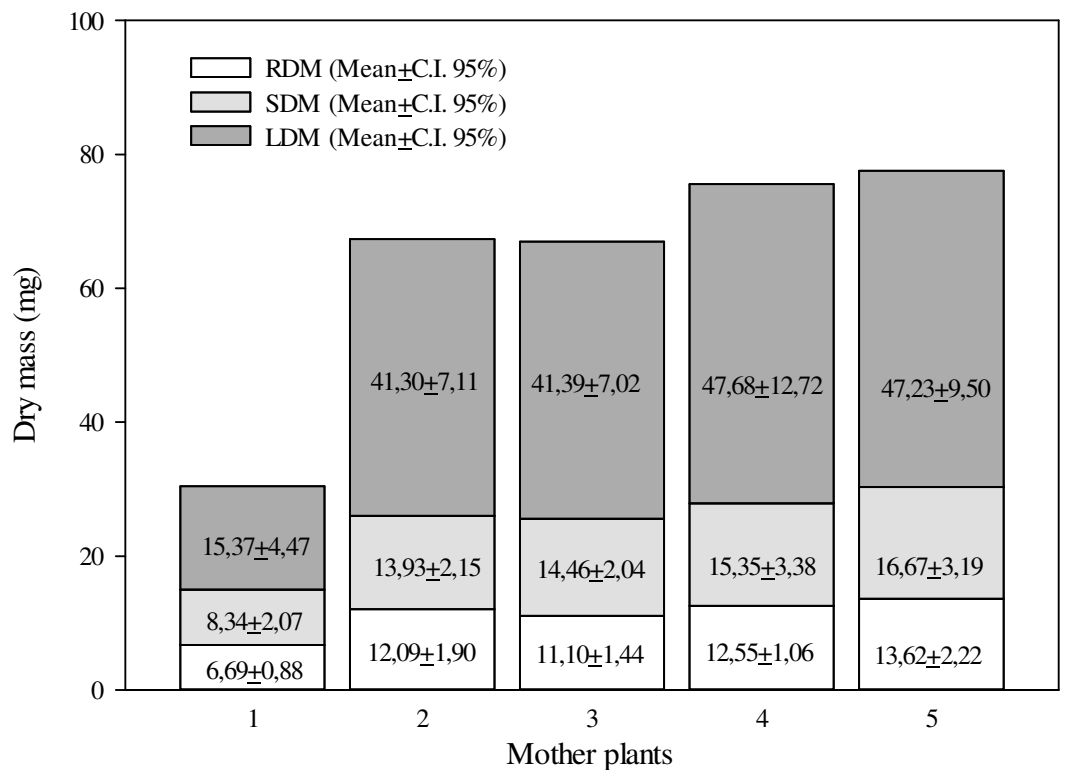

Figure 4. Root dry mass (RDM), stem dry mass (SDM), leaf dry mass (LDM) of five C. leprosum individuals.

It should therefore avoid working with small number of seeds and a few matrices C. leprosum. Studies indicate that there is significant variation between plants for the biometric features and quality of the seeds, as in the case of Tabebuia chrysotricha (SANTOS et al., 2009), according to these authors, the use of seeds obtained small number of plants can compromise the genetic representation of the species.

\section{CONCLUSION}

Combretum leprosum seeds from different mother plants has variability in emergence and biometrics in fruits and seeds. 
RESUMO: Combretum leprosum Mart. é uma espécie medicinal do cerrado brasileiro com uso potencial na regeneração de áreas degradadas, principalmente por ser resistente à queimada. O objetivo deste trabalho foi avaliar a morfometria de frutos e sementes, emergência e desenvolvimento inicial de C. leprosum. As sementes de $C$. leprosum foram extraídas de frutos maduros de cinco plantas-mãe diferentes em Mossoró-RN. Os lotes de frutos e sementes variaram em comprimento, diâmetro e massa e a planta-mãe 1 apresentou os menores diâmetros e massa de sementes e também as menores médias para todas as características avaliadas das mudas. As sementes da planta-mãe 2, 3 e 5 tiveram um curto período de emergência. Houve variação nas taxas de emergência entre os indivíduos. Os indivíduos de Combretum leprosum tem variabilidade na emergência e biometria de sementes, e essas características influenciam a qualidade das mudas.

PALAVRAS ChAVE: Mofumbo. Planta Medicinal. Variabilidade. Caatinga.

\section{REFERENCES}

BOGNOUNOU, F.; THIOMBIANO, A.; ODEN, P. C.; GUINKO, S. Seed provenance and latitudinal gradient effects on seed germination capacity and seedling establishment of five indigenous species in Burkina Faso. Tropical Ecology, Cambridge. 51, n. 2, p. 207-220, 2010. http://www.tropecol.com/pdf/open/PDF_51_2/Jour7.pdf

BORGES, E. E. L.; RENA, A. Germinação de sementes. In: AGUIAR, I. B.; PINÃ-RODRIGUES, F. C. M.; FIGLIOLIA, M. B. Sementes florestais tropicais. Brasília: Abrates, p. 83-135, 1993.

BORGES, V. P.; SILVA, B. B.; ESPÍNOLA SOBRINHO, J.; FERREIRA, R. C.; OLIVEIRA, A. D.; MEDEIROS, J. F. Energy balance and evapotranspiration of melon grown with plastic mulch in the Brazilian semiarid region. Scientia Agricola, Piracicaba, v. 72, n. 5, p. 385-392, 2015. http://dx.doi.org/10.1590/01039016-2014-0136

BRASIL. Regras para análise de sementes. Brasília, Ministério da Agricultura, Pecuária e Abastecimento, Secretaria de Defesa Agropecuária. 2009. 399p.

CARVALHO, A. C. M.; FREITAS, M. L. M.; MORAES, S. M. B.; MORAES, M. L. T.; STRANGHETTI, V.; ALZATE-MARIN, A. L.; SEBBENN, A. M. Diversidade genética, endogamia e fluxo gênico em pequena população fragmentada de Copaifera langsdorffii. Revista Brasileira de Botânica, São Paulo, v. 33, n. 4, p. 599-606, 2010. http://dx.doi.org/10.1590/S0100-84042010000400008

FERREIRA, D. F. Sisvar: a statistic alanalysis computer system. Ciência e agrotecnologia, Lavras, v. 35, n. 6, p. 1039-1042, 2011. http://dx.doi.org/10.1590/S1413-70542011000600001

KOPPER, A. C.; MALAVASI, M. M.; MALAVASI, U. C. Influência da temperatura e do substrato na germinação de sementes de Cariniana estrellensis (Raddi) Kuntze. Revista Brasileira de Sementes, Londrina, v. 32, n. 2, p. 160-165, 2010. http://dx.doi.org/10.1590/S0101-31222010000200020

LABOURIAU, L. G. A germinação das sementes. Washington: Secretaria geral da Organização dos Estados Americanos, 1983. 174p.

LARENTIS, T. C.; SANTIAGO, E. F. Influência do tamanho da semente na germinação e analise morfoanatômica de plântulas de Cecropia pachystachya Trec. (Urticaceae). 2011. http://periodicos.uems.br/index.php/enic/article/view/2102

LORENZI, H.; MATOS, F. J. A. Plantas medicinais no Brasil: nativas e exóticas. Nova Odessa: Plantarum, 2008, 544p.

MARCOS FILHO, J. Fisiologia de sementes de plantas cultivadas. Piracicaba: FEALQ, 2015. 795p. 
OLIVEIRA, D. A.; YULE, R. F.; ROCHA, E. A.; BRAGA, R. F.; PIMENTA, M. A.; SILVA, V.; MAGALHÃES, M. D. Potencial germinativo de sementes de fava-d'anta (Dimorphandra mollis Benth. Fabaceae: Mimosoideae) sob diferentes procedências, datas de coleta e tratamentos de escarificação. Revista Árvore, Viçosa, v. 32, n. 6, p. 1001-1009, 2008. http://dx.doi.org/10.1590/S0100-67622008000600005

PACHECO, M. V.; ARAÚJO, F. S.; FERRARI, C. S.; BRUNO, R. L. A. Germinaçao de sementes de Combretum leprosum Mart. Revista Caatinga, Mossoró, v. 27, n. 1, p. 154-162, 2014.

http://periodicos.ufersa.edu.br/revistas/index.php/sistema/article/view/2729

PAULA, M. F. B.; BRAGA, R. F.; MOREIRA, P. A.; RODRIGUES, L. A.; PIMENTA, M. A. S.; OLIVEIRA, D. A. Caracterização de acessos de fava d'anta (Dimorphandra mollisBenth.) por meio de marcadores moleculares RAPD. Revista Brasileira de Biociências, Porto Alegre, v. 5, n.2, p. 282-284, 2007. http://www.ufrgs.br/seerbio/ojs/index.php/rbb/article/view/308/269

QUIRINO, Z. G. M.; MACHADO, I. C. Biologia da polinização e da reprodução de três espécies de Combretum Loefl. (Combretaceae). Revista Brasileira de Botânica, São Paulo, v. 24, n. 2, p. 181-193, 2001. http://dx.doi.org/10.1590/S0100-84042001000200008

RODRIGUES, P. M. S.; SILVA, H.; BRAGA, L. L.; NUNES, Y. R. F.; VELOSO, M. M.; GONZAGA, A. P. D. Efeito da luz e da procedência na germinação de sementes de Copaifera langsdorffii Desf. (FabaceaeCaesalpinoideae). Revista Brasileira de Biociências, Porto Alegre, v. 5, n. 2, p. 264-266, 2007. http://www.ufrgs.br/seerbio/ojs/index.php/rbb/article/view/242/232

SANTANA, D. G.; ANASTÁCIO, M. R.; LIMA, J. A.; MATTOS, M. B. Germinação de sementes e emergência de plântulas de pau-santo: uma análise crítica do uso de correlação. Revista Brasileira de Sementes, Londrina, v. 32, n. 3, p. 134-140, 2010. http://www.scielo.br/pdf/rbs/v32n3/v32n3a15.pdf

SANTOS, F. S.; PAULA, R. C.; SABONARO, D. Z.; VALADARES, J. Biometria e qualidade fisiológica de sementes de diferentes matrizes de Tabebuia chrysotricha (Mart. Ex A. DC.) StandI. Scientia Forestalis, Piracicaba, v. 37, n. 82, p. 163-173, 2009. http://www.ipef.br/publicacoes/scientia/nr82/cap06.pdf

WIELEWICKI, A. P.;LEONHARDT, C.; SCHLINDWEIN, G.; MEDEIROS, A. C. S. Proposta de padrões de germinação e teor de água para sementes de algumas espécies florestais presentes na região sul do Brasil.

Revista Brasileira de Sementes, Londrina, v. 28, n.191-197, 2006. http://www.scielo.br/pdf/rbs/v28n3/27.pdf 